Imágenes en Urología

\title{
Litiasis vesical secundaria a migración de un fragmento óseo
}

\author{
José Segarra Tomás*, Helena Ascaso Til*, Félix Millán Rodríguez*, Silvia Gracia García**,
} Yolanda Arce Terroba***, Humberto Villavicencio Mavrich*

*Servicio Urología, **Servicio de Laboratorio, ***Servicio de Anatomía Patológica. Fundació Puigvert. Barcelona, España

$\mathrm{M}$ ujer de 61 años que consultó por sindrome miccional de larga evolución. Antecedentes patológicos: cistectomía parcial en otro centro por sospecha de tumor vesical (Anatomía patológica negativa).

En nuestro centro, es diagnosticada de litiasis vesical de gran tamaño (Fig. 2B) por lo que se practicó una cistolitotomía, extrayéndose tres litiasis vesicales (Fig. 3A), cuyo análisis cristalográfico muestra una zona nuclear de gran dureza, estructura compacta, con oquedades y zonas con estructura "trabecular" (Fig. 3B). Esta zona, correspondiente al núcleo, se halla envuelta por una segunda fase de estructura granular formada por fosfato

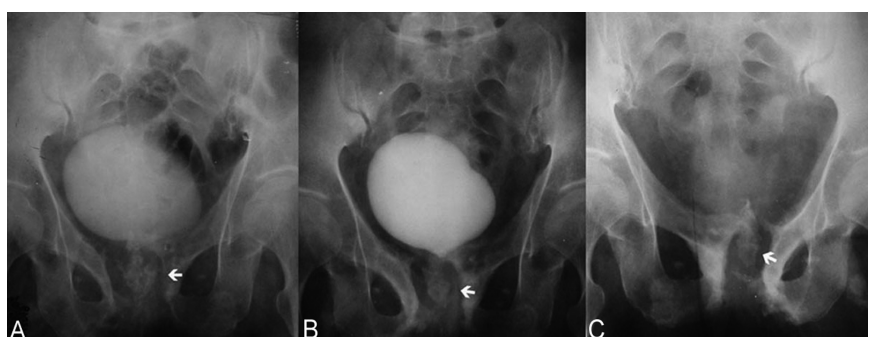

FIGURA 1. Secuencia radiológica de la migración de un islote óseo de la sinfisis del pubis hasta la vejiga. A: UIV. B: UIV 2 años más tarde C: Rx simple 1 año después.

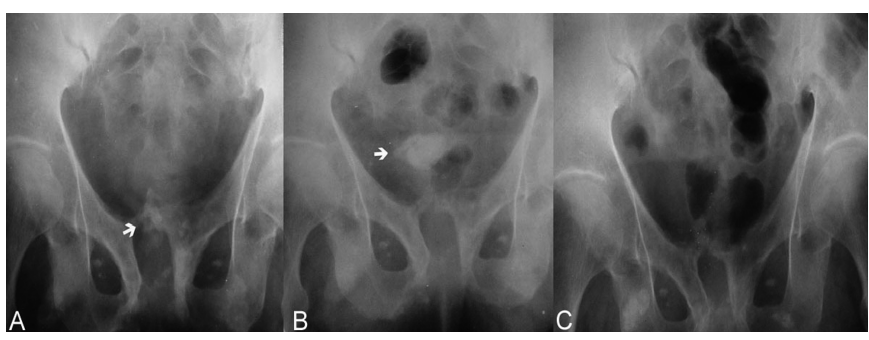

FIGURA 2. Continuación de la secuencia de migración. A: Rx simple, donde la flecha muestra el islote óseo ascendiendo. B: Rx simple con imágenes cálcicas en vejiga. (Primera $R x$ realizada en nuestro centro). C: Resultado final tras cistolitotomia. amónico magnésico y carbonatoapatita. El estudio anatomopatológico demuestra que esta estructura central es hueso. (Fig. 3C). Tras este hallazgo, se solicitó el historial médico de la paciente, observando en los estudios radiológicos aportados, la presencia de un fragmento óseo que a lo largo de los años migra desde la sínfisis del pubis hasta la vejiga.

Correspondencia autor: Dra. Helena Ascaso Til

Servicio de Urología. Fundació Puigvert

Cartagena, 340-350 - 08025 Barcelona

Tel.: 932275400

E-mail autor: hascasotil@yahoo.es

Información artículo: Imágenes en Urología

Trabajo recibido: septiembre 2007

Trabajo aceptado: octubre 2007

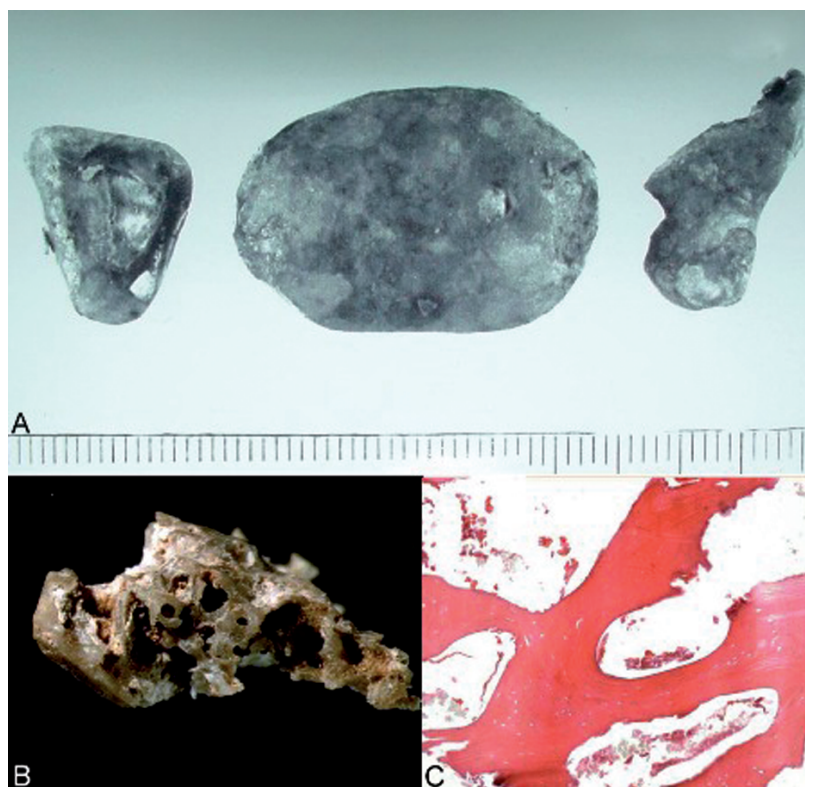

FIGURA 3. A: Litiasis extraidas por cistolitotomia. B: Núcleo de la litiasis. C: Imagen microscópica de trabéculas óseas. 